\title{
FLT4 wt Allele
}

National Cancer Institute

\section{Source}

National Cancer Institute. FLT4 wt Allele. NCI Thesaurus. Code C51547.

Human FLT 4 wild-type allele is located within $5 q 34-q 35$ and is approximately $47 \mathrm{~kb}$ in length. This allele, which encodes vascular endothelial growth factor receptor 3 protein, plays a role in the development of the embryonic cardiovascular system before the emergence of lymphatic blood vessels. 